\title{
Pengaruh Firm Size dan Leverage terhadap Agresivitas Pajak dengan Pengungkapan Corporate Social Responsibility sebagai Variabel Pemoderasi
}

\author{
Mochamad Romdhon $^{1}$; Erik Kartiko² ; Sayyidah Nurjamilah $^{3}$ \\ ${ }^{1}$ Universitas Garut \\ mromdhon@uniga.ac.id \\ ${ }^{2}$ Universitas Garut \\ erikkartiko@uniga.ac.id \\ ${ }^{3}$ Universitas Garut \\ 24022116152@fekon.uniga.ac.id
}

\begin{abstract}
Abstrak
Tujuan penelitian ini adalah untuk mengetahui pengaruh ukuran perusahaan dan leverage terhadap agresivitas pajak dengan pengungkapan Corporate Social Responsibility sebagai variabel moderasi pada perusahaan sektor pertambangan yang terdaftar di Bursa Efek Indonesia periode 2014-2018. Data yang digunakan dalam penelitian ini berasal dari laporan tahunan dan laporan keuangan konsolidasi periode 2014 hingga 2018. Teknik pengambilan sampel menggunakan metode purposive sampling dengan jumlah sampel sebanyak 10 perusahaan. Teknik analisis data yang digunakan adalah statistik deskriptif, uji analisis regresi berganda, dan Moderated Regression Analysis (MRA). Hasil penelitian menunjukkan bahwa ukuran perusahaan berpengaruh negatif signifikan terhadap agresivitas pajak. Hal ini bertentangan dengan leverage yang tidak berpengaruh signifikan terhadap agresivitas pajak. Pengungkapan Corporate Social Responsibility memperlemah pengaruh ukuran perusahaan terhadap agresivitas pajak. Dan pengungkapan Corporate Social Responsibility juga memperlemah pengaruh leverage terhadap agresivitas pajak.
\end{abstract}

Kata Kunci: Agresivitas Pajak, Leverage, Pengungkapan Tanggung Jawab Sosial Perusahaan, Ukuran Perusahaan

\begin{abstract}
The research objective was to determine the effect of Firm Size and Leverage on tax aggressiveness with Corporate Social Responsibility disclosure as a moderating variable in mining sector companies listed on the Indonesia Stock Exchange for the 2014-2018 period. The data used in this study came from annual reports and consolidated financial reports for the period 2014 to 2018. The sampling technique used a purposive sampling method with a total sample of 10 companies. The data analysis technique used is descriptive statistics, multiple regression analysis tests, and Moderated Regression Analysis (MRA). The results showed that Firm Size has a significant negative effect on tax aggressiveness. It is contrary to Leverage that does not have a significant effect on Tax Aggressiveness.
\end{abstract}


The Disclosure of Corporate Social Responsibility weakens the influence of Firm Size on Tax Aggressiveness. And the disclosure of Corporate Social Responsibility also weakens the influence of Leverage on Tax Aggressiveness.

Keywords: Corporate Social Responsibility Disclosure, Firm Size, Leverage, Tax Aggressiveness.

\section{Pendahuluan}

Sektor perpajakan sendiri merupakan sumber pendapatan terbesar bagi Indonesia, hal tersebut salah satunya dapat dilihat dari realisasi penerimaan negara tahun 2014-2018 berikut ini:

Tabel 1: Realisasi penerimaan negara tahun 2014-2018 (dalam milyar rupiah)

\begin{tabular}{rrrrrr}
\hline Sumber Penerimaan & $\mathbf{2 0 1 4}$ & $\mathbf{2 0 1 5}$ & $\mathbf{2 0 1 6}$ & $\mathbf{2 0 1 7}$ & $\mathbf{2 0 1 8}$ \\
\hline Penerimaan & $\mathbf{1 . 1 4 6 . 8 6 5 , 8}$ & $\mathbf{1 . 2 4 0 . 4 1 8 , 8}$ & $\mathbf{1 . 2 8 4 . 9 7 0 , 1}$ & $\mathbf{1 . 3 4 3 . 5 2 9 , 8}$ & $\mathbf{1 . 5 4 8 . 4 8 5 , 0}$ \\
Perpajakan & $\mathbf{0}$ & $\mathbf{6}$ & $\mathbf{0}$ & $\mathbf{0}$ & $\mathbf{0}$ \\
\hline Penerimaan bukan & $398.590,50$ & $255.628,48$ & $261.976,30$ & $311.216,30$ & $349.158,30$ \\
Pajak & & & & & \\
\hline Jumlah/Total & $1.545 .456,3$ & $1.496 .047,3$ & $1.546 .946,6$ & $1.654 .746,1$ & $1.897 .643,4$ \\
& 0 & 3 & 0 & 0 & 0 \\
\hline
\end{tabular}

Sumber : $\underline{\text { www.bps.go.id }}$

Berdasarkan tabel tersebut, hasilnya menunjukkan tren yang positif dan dapat disimpulkan bahwa memang benar pendapatan terbesar bagi negara berasal dari pajak, sehingga wajar jika pemerintah menaruh perhatian lebih pada sektor perpajakan.

Di Indonesia usaha-usaha untuk menggenjot atau mengoptimalkan penerimaan sektor pajak dilakukan melalui usaha intensifikasi dan ekstensifikasi penerimaan pajak (Surat direktur jenderal pajak No. S 14/PJ.7/2003, 2003). Upaya yang telah dilakukan oleh pemerintah tersebut tentunya bukan tanpa hambatan, tujuan perusahaan untuk memaksimalkan keuntungan melalui tindakan efisiensi pajak bertentangan dengan tujuan pemerintah untuk memaksimalkan penerimaan negara dari sektor pajak. Perusahaan berusaha untuk mengefisiensikan beban pajaknya sehingga memperoleh keuntungan yang lebih besar dalam rangka mensejahterakan shareholder dan mempertahankan keberlanjutan perusahaan di masa depan. Namun disisi lain, berkurangnya penerimaan negara dari sektor pajak berdampak negatif pada penyediaan fasilitas publik bagi masyarakat. Hal ini menunjukkan bahwa pajak merupakan salah satu tanggung jawab dan wujud kontribusi perusahaan terhadap sosial dan masyarakat di suatu negara (Gunawan, 2017). Adanya perbedaan kepentingan dari negara yang menginginkan penerimaan pajak sebesar mungkin bertentangan dengan keinginan perusahaan untuk mengeluarkan pajak serendah mungkin, sehingga kadangkala menyebabkan timbulnya tindakan untuk melakukan perlawanan terhadap pajak melalui upaya-upaya atau strategi untuk mengurangi pajak yang disebut sebagai tindakan agresif terhadap pajak.

Kegiatan agresivitas pajak tergolong socially irresponsible karena berdampak pada masyarakat luas, hal ini tidak sesuai dengan harapan masyarakat yang mana karena pembayaran pajak perusahaan memiliki implikasi penting bagi pendanaan publik seperti pendidikan, pertahanan nasional, kesehatan masyarakat dan hukum. Padahal di sisi lain pertanggungjawaban sosial ini 
merupakan faktor utama dalam kelangsungan hidup suatu perusahaan (Lanis \& Richardson, 2012).

Terdapat beberapa faktor yang mempengaruhi perusahaan untuk membayar pajak, salah satunya adalah Firm Size atau ukuran perusahaan. Penelitian mengenai pengaruh ukuran perusahaan terhadap Agresivitas Pajak telah banyak dilakukan, namun terdapat perbedaan hasil penelitian dan juga perbedaan teori yang digunakan. Menurut Richardson dan Lannis (2007) terdapat 2 teori mengenai ukuran perusahaan, yakni teori Political Power dan teori Political Cost. Selain ukuran perusahaan, faktor lain yang mempengaruhi perusahaan dalam membayar pajaknya adalah Leverage. Perusahaan dapat menggunakan tingkat Leverage untuk mengurangi laba dan akan berpengaruh terhadap berkurangnya beban pajak (Brigham \& Houston, 2010 dalam Sukmawati dan Rebecca, 2016).

Untuk di Indonesia sendiri, belum lama ini sebuah laporan yang dikeluarkan oleh Global Witness menyebutkan bahwa perusahaan tambang besar di Indonesia, PT Adaro Energy Tbk disebut melakukan penghindaran pajak dengan cara transfer pricing melalui anak usahanya di Singapura, Coaltrade Services International. Upaya itu disebutkan telah dilakukan sejak 2009 hingga 2017. Pertama, Adaro menjual batu bara yang ditambang di Indonesia dengan harga rendah kepada Coaltrade yang kemudian untuk dijual kembali oleh anak perusahaan itu dengan harga lebih tinggi. Selama 2009-2017, Global Witness mencatat lebih dari 70 persen batu bara yang dijual Coaltrade berasal dari tambang batu bara Adaro di Indonesia. Kedua, Global Witness juga mendapati Coaltrade menerima komisi dari pihak ketiga dan anak perusahaan Adaro lainnya yang bernilai sekitar 4 juta dolar AS per tahun sebelum 2009. Lalu, antara 20092017, angka itu berubah menjadi 55 juta dolar AS per tahun. Coaltrade pun memanfaatkan peluang ini untuk memperoleh laba dan membukukannya di Singapura yang notabene tarif pajaknya lebih rendah dari Indonesia. Nilai pajak yang dapat dikumpulkan Direktorat Jenderal Pajak (DJP) mencapai 125 juta dolar AS dari pajak penghasilan perusahaan atau setara 14 juta dolar AS per tahunnya (finance.detik.com).

Fenomena di atas membuktikan bahwa tindakan agresivitas pajak merupakan isu yang penting untuk mendapatkan perhatian lebih. Di sisi lain, Indonesia sendiri untuk sektor pertambangan khususnya dalam pertambangan batu bara merupakan pemain kunci dalam percaturan industri pertambangan batu bara dunia. Selama puluhan tahun, industri batu bara selalu dianakemaskan oleh negara lantaran kontribusinya besar dalam perekonomian nasional. Bahkan, kala krisis ekonomi global 2008 melanda, berkat sumbangsih industri batu bara maka kondisi ekonomi Indonesia masih tetap tumbuh (www.katadata.co.id).

\section{Tinjauan Pustaka}

\subsection{Agresivitas Pajak}

Pajak menurut UU Nomor 28 Tahun 2007 tentang Ketentuan Umum Tata Cara Perpajakan pasal 1 ayat 1 adalah : "kontribusi wajib kepada negara yang terutang oleh pribadi atau badan yang bersifat memaksa berdasarkan undang undang dengan tidak mendapatkan imbalan secara langsung dan digunakan untuk keperluan negara bagi sebesar-besarnya kemakmuran rakyat". Manajemen pajak menurut Mangoting (1999) dalam (Andrianto \& Fadjar , 2017) adalah sarana untuk memenuhi kewajiban perpajakan dengan benar tetapi jumlah pajak yang dibayar dapat ditekan serendah mungkin untuk memperoleh laba dan likuiditas yang diharapkan manajemen. 
Menurut Hanlon (2010) dalam (Anis, 2017) bahwa terdapat beberapa istilah terkait digunakan untuk menggambarkan agresivitas penurunan pajak seperti tax planning, tax avoidance, tax evasion, dan tax sheltering. Perusahaan yang dikatakan paling agresif terhadap pajak akan memastikan untuk membuat setiap transaksi atau opsi yang dapat mengurangi pajak digunakan dalam setiap kesempatan. Ketika sebuah perusahaan beroperasi dalam rezim yang hukum perpajakannya samar-samar dan dapat diinterpretasikan secara terbuka, perusahaan tersebut akan cenderung untuk mengasumsikan posisi pajak yang paling menguntungkan bagi dirinya. Perusahaan tersebut akan selalu mencari alternatif-alternatif dalam menyusun transaksitransaksinya yang dapat menghasilkan penghematan pajak (tax savings) yang lebih besar. Tingkat agresivitas pajak yang lebih besar tidak selalu menyiratkan tax abusiveness, namun tentunya terdapat risiko dalam pengurangan kewajiban pajak eksplisit yang dilakukan secara sengaja, di mana entitas mengadopsi langkah-langkah yang menyalahgunakan hukum atau substansi hukum yang bertentangan dengan bentuk hukum (the legal form) (Martinez, 2017).

\subsection{Firm Size}

Firm Size atau ukuran perusahaan merupakan suatu pengukuran yang mengelompokkan skala besar kecil nya perusahaan yang dapat dilihat dari berbagai hal baik total aktiva nya maupun dari tingkat penjualannya, yang mana pengukuran ini merupakan gambaran dari aktivitas dan pendapatan perusahaan tersebut. Perusahaan yang memiliki total aset besar menunjukan bahwa perusahaan tersebut telah memiliki prospek yang sangat baik dalam jangka waktu yang relatif lama, dan juga mencerminkan kondisi perusahaan relatif lebih stabil dan mampu menghasilkan laba.

Berdasarkan dari adanya Political Power theory yang menyatakan bahwa perusahaan besar dapat menggunakan sumber dayanya untuk memanfaatkan proses politik yang dapat menguntungkan perusahaan dan mengefisienkan beban pajak perusahaan dan juga adanya Political Cost theory yang menyatakan bahwa perusahaan besar tidak dapat menggunakan kekuatannya untuk melakukan perencanaan pajak karena perusahaan tersebut menjadi sorotan dari pembuat kebijakan (Fatharani, 2012). Selain itu perusahaan yang beroperasi lintas negara memiliki kecenderungan untuk melakukan tindakan penghindaran pajak yang lebih tinggi dibandingkan perusahaan yang beroperasi lintas domestik, karena mereka bisa melakukan transfer laba ke perusahaan yang ada di negara lain, yang mana negara tersebut memungut tarif pajak yang lebih rendah dibandingkan negara lainnya (Marfu'ah, 2015).

\subsection{Leverage}

Leverage menurut Subakti (2012) merupakan tingkat hutang yang digunakan perusahaan dalam melakukan pembiayaan. Leverage diukur dengan membandingkan total kewajiban perusahaan dengan total aktiva yang dimiliki perusahaan (Dewi \& Noviari, 2017). Leverage digunakan untuk mengukur kemampuan suatu perusahaan untuk dapat membayar seluruh kewajiban baik jangka pendek maupun jangka panjang. Penggunaan hutang dalam membiayai kegiatan operasional perusahaan akan menimbulkan bunga, biaya bunga dapat dikurangkan dari pajak. Leverage merupakan tingkat utang yang digunakan perusahaan dalam melakukan pembiayaan. Semakin tinggi Leverage dalam suatu perusahaan maka beban pajak yang ditanggung oleh perusahaan akan berkurang, sehingga langkah utang lebih dipilih oleh manajemen sebagai upaya menghindari beban pajak yang lebih besar. Meskipun tidak semua beban bunga dapat dibebankan terkait aturan yang ditetapkan oleh fiskus (Barli, 2018). Di sisi lain, semakin tinggi debt ratio yang dimiliki suatu perusahaan juga dapat mengakibatkan semakin besar risiko yang dihadapi dan tuntutan investor untuk meminta 
keuntungan semakin tinggi. Rasio yang tinggi juga dapat menunjukkan rasio modal sendiri yang rendah untuk membiayai aktiva (Pranjoto, 2013).

\subsection{Corporate Social Responsibility (CSR)}

Definisi Corporate Social Responsibility berdasarkan Undang-Undang nomor 40 tahun 2007 tentang Perseroan Terbatas, adalah : "Tanggungjawab sosial dan lingkungan adalah komitmen perseroan untuk berperan serta dalam pembangunan ekonomi berkelanjutan guna meningkatkan kualitas kehidupan dan lingkungan yang bermanfaat, baik bagi perseroan sendiri, komunitas setempat, maupun masyarakat pada umumnya."

Pengungkapan CSR telah diatur dalam UU Perseroan Terbatas No.40 tahun 2007 pasal 66 ayat (2) yang menyebutkan bahwa semua perseroan wajib untuk melaporkan pelaksanaan tanggung jawab tersebut dalam Laporan Tahunan. Dengan mengungkapkan CSR perusahaan memang tidak akan mendapatkan profit atau keuntungan secara langsung, namun yang diharapkan dari kegiatan ini adalah benefit berupa image perusahaan. Menurut Gunawan (2012) pelaporan aktivitas CSR perusahaan dapat dipergunakan sebagai salah satu alat evaluasi atas kinerja perusahaan serta dianggap sebagai praktik akuntabilitas perusahaan.

Aktivitas CSR dapat dilaporkan dalam dua jenis laporan yaitu menjadi bagian laporan tahunan atau terpisah dari laporan tahunan, yaitu dalam laporan keberlanjutan. Pedoman standar pelaporan aktivitas CSR pada laporan keberlanjutan dikembangkan oleh the Global Reporting Initiative (GRI) yang telah diterapkan di seluruh negara. Mulai Mei 2013, standar pelaporan CSR dalam laporan keberlanjutan yang dipakai adalah GRI versi 4 (Gunawan, 2017). GRI-G4 menyediakan kerangka kerja yang relevan secara global untuk mendukung pendekatan yang terstandarisasi dalam pelaporan yang mendorong tingkat transparansi dan konsistensi yang diperlukan untuk membuat informasi yang disampaikan menjadi berguna dan dapat dipercaya oleh pasar dan masyarakat. Dalam standar GRI G-4, indikator kinerja dibagi menjadi tiga komponen utama, yaitu ekonomi, lingkungan hidup dan sosial. Kategori sosial mencakup hak asasi manusia, praktek ketenagakerjaan dan lingkungan kerja, tanggung jawab produk dan masyarakat. Total indikator yang terdapat dalam GRI mencapai 91 item (www.globalreporting.org).

\subsection{Kerangka Pemikiran}

Berdasarkan landasan teori dan beberapa penelitian terdahulu, penelitian ini menguji Firm Size dan Leverage terhadap agresivitas pajak perusahaan dengan melibatkan pengungkapan CSR sebagai pemoderasi yang mana keterkaitannya digambarkan dalam kerangka pemikiran sebagai berikut:

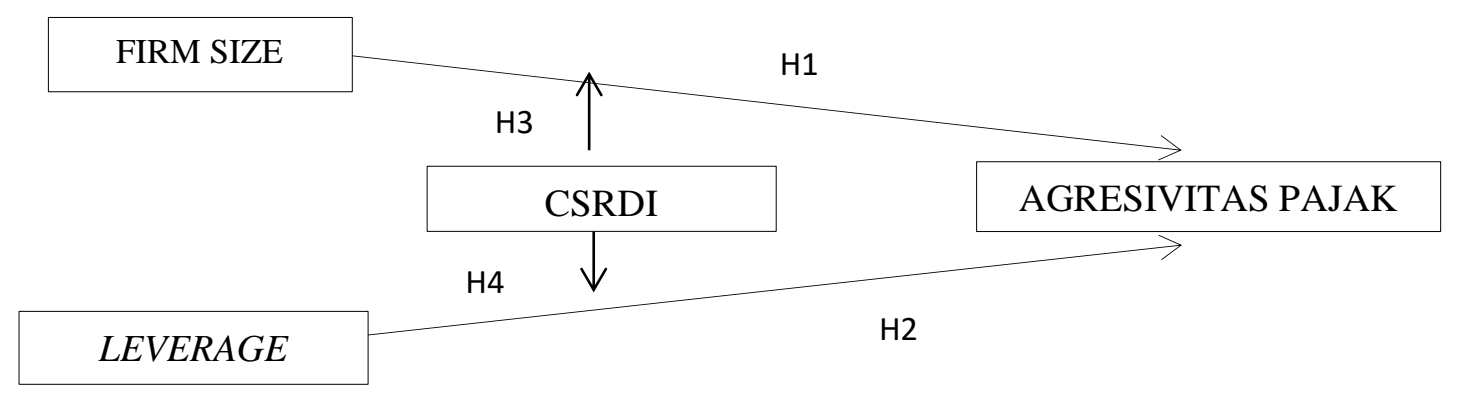

Gambar 1: Kerangka pemikiran 
Berikut adalah hipotesis berdasarkan kerangka pemikiran diatas:

H1 : Firm Size berpengaruh positif dan signifikan terhadap Agresivitas Pajak

$\mathrm{H} 2$ : Leverage berpengaruh negatif pada terhadap agresivitas pajak

H3 : Corporate Social Responsibility memperkuat pengaruh antara Firm Size terhadap Agresivitas Pajak

H4 : Corporate Social Responsibility memperkuat pengaruh antara Leverage terhadap Agresivitas Pajak.

\section{$3 \quad$ Metode Penelitian}

Metode penelitian yang digunakan dalam penelitian ini adalah metode deskriptif dengan pendekatan kuantitatif dan jenis penelitian kausal komparatif.

Tabel 2: Operasionalisasi variabel

\begin{tabular}{|c|c|c|c|}
\hline Variabel & Dimensi & Indikator & Skala \\
\hline Firm Size (X1) & Size & Total Aktiva & Rasio \\
\hline Leverage (X2) & Debt to Asset & - $\quad$ Total hutang & Rasio \\
\hline & Rasio & - Total Aktiva & \\
\hline Agresivitas & Effective Tax & Beban Pajak & Rasio \\
\hline Pajak (Y) & Rasio & - Pendapatan Sebelum Pajak & \\
\hline $\begin{array}{l}\text { Corporate Social } \\
\text { Responsibility }(\mathrm{Z})\end{array}$ & $\begin{array}{l}\text { Corporate Social } \\
\text { Responsibility } \\
\text { Disclosure Indeks }\end{array}$ & $\begin{array}{l}\text { - Total angka atau skor yang didapat } \\
\text { oleh masing-masing perusahaan } \\
\text { - Jumlah item untuk perusahaan }\end{array}$ & Rasio \\
\hline
\end{tabular}

Populasi dalam penelitian ini adalah perusahaan-perusahaan sektor pertambangan yang terdaftar di Bursa Efek Indonesia pada tahun 2014-2018 sebanyak 42 perusahaan. Pemilihan sampel dalam penelitian ini menggunakan metode nonprobability sampling yakni purposive sampling dengan kriteria sampel sebagai berikut :

Tabel 3: Kriteria populasi

\begin{tabular}{clc}
\hline No. & \multicolumn{1}{c}{ Total Populasi } & \multicolumn{1}{c}{ Kriteria } \\
\cline { 2 - 3 } $\mathbf{1}$ & $\begin{array}{l}\text { Perusahaan yang tidak mempublikasikan laporan tahunan (annual report) dan } \\
\text { laporan keuangan secara berturut-turut selama tahun penelitian }\end{array}$ & $(8)$ \\
\hline $\mathbf{2}$ & $\begin{array}{l}\text { Perusahaan yang mengalami kerugian dan terdapat kompensasi pajak akibat rugi } \\
\text { selama tahun penelitian }\end{array}$ & $(21)$ \\
\hline $\mathbf{3}$ & $\begin{array}{l}\text { Perusahaan yang tidak menyajikan pengungkapan CSR dalam laporan } \\
\text { tahunannya secara berturut-turut selama tahun penelitian }\end{array}$ & $(3)$ \\
\hline Total Sampel & 10 \\
\hline Data dalam 5 tahun penelitian & 50 \\
\hline
\end{tabular}

Jenis data yang digunakan adalah data sekunder yang berupa laporan tahunan perusahaan meliputi perusahaan sektor pertambangan yang telah listing di BEI pada tahun 2014-2018 yang diperoleh dari situs Bursa Efek Indonesia yaitu www.idx.co.id. 
Penelitian ini menggunakan aplikasi SPSS (Statistical Package for Special Science) versi 25 untuk mengolah data. Adapun untuk analisis dan rancangan pengujian hipotesisnya menggunakan :

1. Analisis Regresi Linier Berganda, dengan persamaan berikut :

$$
\text { LnTAGit }=\alpha_{0}+\beta_{1} \operatorname{LnSIZE}+\beta_{2} \operatorname{LnLEV}+e
$$

2. Moderated Regression Analysis, dengan persamaan berikut :

LnTAGit $=\alpha_{0}+\beta_{1}$ LnSIZE $+\beta_{2}$ LnLEV $+\beta_{3}$ LnCSRDI $+\beta_{4}($ LnSIZE $*$ LnCSRDI $)+$ $\beta_{5}(\operatorname{LnLEV} * \operatorname{LnCSRDI})+\mathrm{e}$

\section{$4 \quad$ Hasil Penelitian dan Pembahasan}

Jumlah seluruh sampel dalam penelitian ini adalah 10 perusahaan pertambangan dikalikan 5 tahun dari periode 2014-2018 yang berarti terdapat 50 unit analisis. Berikut adalah hasil analisis statistik deskriptifnya :

Tabel 4: Hasil analisis statistik deskriptif

\begin{tabular}{lrrrrr}
\hline & N & Minimum & Maximum & Mean & Std. Deviation \\
\hline SIZE & 50 & 18,41 & 22,68 & 20,1394 & 1,20665 \\
\hline LEV & 50 &, 14 &, 67 &, 4000 &, 12194 \\
\hline TAX & 50 &, 20 &, 58 &, 3302 &, 09148 \\
\hline CSR & 50 &, 09 &, 73 &, 3326 &, 14588 \\
\hline Valid N (listwise) & 50 & & & & \\
\hline
\end{tabular}

Sebelum melakukan analisis terhadap hasil regresi, pemenuhan asumsi klasik diuji terhadap model regresi dalam penelitian ini. Hasil uji normalitas data menunjukkan bahwa nilai test statistic Kolmogotov-Smirnov sebesar 0,100 dan tidak signifikan pada 0,05 (karena p > 0,05), dengan kata lain residual berdistribusi normal. Serta hasil perhitungan VIF pun menunjukkan tidak ada satupun variabel independen yang memiliki VIF lebih dari 10, sehingga dapat diartikan bahwa tidak ada multikolonieritas antar variabel independen dalam model regresi. $\mathrm{H}]$ Hasil uji autokorelasi dengan menggunakan Runtest menunjukan bahwa nilai test adalah 0,01748 dengan probabilitas 0,775 dengan signifikan 0,05 , sehingga dapat dikatan bahwa tidak terjadi autokorelasi.

\section{Hasil Uji Koefisien Determinasi}

Tabel 5: Hasil uji koefisien determinasi

\begin{tabular}{|c|c|c|c|c|c|}
\hline \multicolumn{6}{|c|}{ Model Summary } \\
\hline Model & $\mathrm{R}$ & R Square & $\begin{array}{l}\text { Adjusted R } \\
\text { Square }\end{array}$ & $\begin{array}{l}\text { Std. Error of the } \\
\text { Estimate }\end{array}$ & Durbin-Watson \\
\hline 1 &, $559^{\mathrm{a}}$ & ,312 & ,267 & ,22547 & 1,850 \\
\hline
\end{tabular}

Koefisien determinasi (R2) digunakan untuk menguji goodness-fit dari suatu model regresi, dan berdasarkan tabel diatas menunjukkan bahwa nilai adjusted $\mathrm{R}$ square sebesar 0,267 yang berarti 
bahwa kemampuan variabel independen dalam menjelaskan variabel dependen sebesar $26,7 \%$ dan sisanya sebesar 73,3\% dipengaruhi oleh variabel lain selain Firm Size dan Leverage.

\section{Hasil Pengujian Hipotesis}

Tabel 6: Hasil uji parsial T

\begin{tabular}{|c|c|c|c|c|c|c|}
\hline \multicolumn{7}{|c|}{ Coefficients $^{\mathrm{a}}$} \\
\hline & \multirow[t]{2}{*}{ Model } & \multicolumn{2}{|c|}{$\begin{array}{l}\text { Unstandardized } \\
\text { Coefficients }\end{array}$} & \multirow{2}{*}{$\begin{array}{c}\begin{array}{c}\text { Standardized } \\
\text { Coefficients }\end{array} \\
\text { Beta }\end{array}$} & \multirow[t]{2}{*}{$\mathbf{t}$} & \multirow[t]{2}{*}{ Sig. } \\
\hline & & B & Std. Error & & & \\
\hline 1 & (Constant) & $-5,829$ & 1,937 & & $\begin{array}{c}- \\
3,010 \\
\end{array}$ & ,004 \\
\hline & SIZE & 1,376 & ,618 & ,310 & 2,227 & ,031 \\
\hline & LEV &,- 164 & ,116 &,- 209 & $\overline{-}^{-} 419$ & , 163 \\
\hline \multicolumn{7}{|c|}{ a. Dependent Variable: TAX } \\
\hline
\end{tabular}

\section{a. Hasil Uji Hipotesis 1}

Berdasarkan hasil uji hipotesis pada tabel diatas koefisien regresi SIZE sebesar 1,376 yang menyatakan bahwa setiap kenaikan Firm Size 1\% akan meningkatkan ETR sebesar 1,376\%. Dengan tingkat signifikansi 0,031 yang berarti kurang dari 0,05, maka dapat dikatakan bahwa variabel Firm Size berpengaruh positif secara signifikan terhadap ETR.

\section{b. Hasil Uji Hipotesis 2}

Berdasarkan hasil uji hipotesis pada tabel 6, koefisien regresi LEV sebesar -0,164 yang menyatakan bahwa setiap kenaikan Leverage 1\% akan menurunkan ETR sebesar 0,164 \%. Dengan tingkat signifikansi 0,163 yang berarti lebih dari 0,05 , maka dapat dikatakan bahwa variabel Leverage berpengaruh negatif dan tidak signifikan terhadap ETR.

\section{c. Hasil Uji Hipotesis 3}

Tabel 7: Hasil uji hipotesis 3

\begin{tabular}{|c|c|c|c|c|c|}
\hline \multicolumn{6}{|c|}{ Model Summary } \\
\hline Model & $\mathbf{R}$ & R Square & $\begin{array}{l}\text { Adjusted R } \\
\text { Square }\end{array}$ & $\begin{array}{l}\text { Std. Error of } \\
\text { the Estimate }\end{array}$ & $\begin{array}{l}\text { Durbin- } \\
\text { Watson }\end{array}$ \\
\hline 1 &, $535^{\mathrm{a}}$ & ,286 & ,240 & ,22968 & 1,934 \\
\hline a. Predic & onsta & SIZE*LEV & $Z E$, CSR & & \\
\hline
\end{tabular}

Nilai $R$ Square pada persamaan pertama pada tabel 5 sebesar 0,312 atau 31,2\%, namun setelah adanya variabel moderasi (pengungkapan CSR) pada persamaan kedua, nilai $R$ Square tersebut menurun menjadi 0,286 atau 28,6\%. Dengan demikian, maka dapat disimpulkan bahwa keberadaan pengungkapan Corporate Social Responsibility (sebagai variabel moderasi) terbukti dapat memperlemah atau menurunkan pengaruh hubungan Firm Size terhadap agresivitas pajak. 


\section{d. Hasil Uji Hipotesis 4}

Tabel 8: Hasil uji hipotesis 4

\begin{tabular}{|c|c|c|c|c|c|}
\hline \multicolumn{6}{|c|}{ Model Summary $^{b}$} \\
\hline Model & $\mathbf{R}$ & R Square & $\begin{array}{l}\text { Adjusted R } \\
\text { Square }\end{array}$ & $\begin{array}{l}\text { Std. Error of } \\
\text { the Estimate }\end{array}$ & $\begin{array}{l}\text { Durbin- } \\
\text { Watson }\end{array}$ \\
\hline 1 &, $517^{\mathrm{a}}$ & 268 & ,220 &, 23265 & 1,892 \\
\hline
\end{tabular}

Nilai $R$ Square pada persamaan pertama pada tabel 5 sebesar 0,312 atau $31,2 \%$, namun setelah adanya variabel moderasi (pengungkapan CSR) pada persamaan kedua, nilai $R$ Square tersebut menurun menjadi 0,268 atau 26,8\%. Dengan demikian, maka dapat disimpulkan bahwa keberadaan pengungkapan Corporate Social Responsibility (sebagai variabel moderasi) terbukti dapat memperlemah atau menurunkan pengaruh Leverage terhadap agresivitas pajak.

Pengujian hipotesis pertama menunjukkan bahwa Firm Size berpengaruh positif dan signifikan terhadap ETR. Hal ini berarti bahwa semakin besar ukuran perusahaan maka akan semakin meningkat pula nilai ETR-nya dan berarti semakin rendah tingkat agresivitas terhadap pajaknya. Penelitian ini mendukung penelitian Widyari \& Rasmini (2019) yang menyatakan bahwa Firm Size berpengaruh negatif terhadap Agresivitas Pajak. Hasil penelitian ini sesuai dengan Political Cost theory yang dinyatakan oleh Richardson dan Lanis (2007) yang mana mempunyai visibilitas tinggi di mana perusahaan besar akan menjadi sorotan pemerintah dan menjadi korban regulasi dari kebijakan pemerintah, sehingga perusahaan besar akan menjaga reputasi perusahaan agar tetap baik di mata publik dan pemerintah dengan melakukan perencanaan pajak yang tidak melanggar ketentuan undang-undang perpajakan.

Pengujian hipotesis kedua menunjukkan bahwa Leverage tidak berpengaruh signifikan terhadap ETR, atau dengan kata lain Leverage tidak berpengaruh signifikan terhadap agresivitas pajak. Hasil penelitian ini konsisten dengan penelitian yang telah dilakukan oleh Susanto, Yanti, \& Viriany, (2018) yang menyatakan bahwa tingkat hutang tidak berpengaruh signifikan terhadap agresivitas pajak. hal ini mengindikasikan bahwa selama periode pengamatan, perusahaan tidak memanfaatkan utang sepenuhnya untuk meminimalkan beban pajak. dalam penelitian ini Leverage tidak berpengaruh terhadap agresivitas pajak sehingga dapat dikatakan adanya kemungkinan bahwa perusahaan dalam menggunakan hutang tidak semata - mata untuk menciptakan pendapatan, mungkin hutang digunakan untuk berinvestasi jangka panjang, sehingga beban bunga tidak timbul perperiode pada laporan keuangan, jadi tidak dapat digunakan sebagai pengurang beban pajak yang harus dibayarkan perusahaan.

Pengujian hipotesis ketiga menunjukkan bahwa CSR tidak berpengaruh signifikan dan memperlemah variabel Firm Size terhadap agresivitas pajak. Firm Size adalah variabel penduga yang banyak digunakan untuk menjelaskan variasi pengungkapan sosial dalam laporan tahunan yang dibuat perusahaan. Hal ini dihubungkan dengan agency theory yang memprediksi bahwa perusahaan besar yang mempunyai biaya keagenan yang lebih tinggi akan mengungkapkan informasi lebih luas dengan tujuan mengurangi biaya keagenan yang tinggi tersebut. Selain itu, perusahaan besar juga merupakan emiten yang banyak disoroti oleh publik, pengungkapan yang lebih besar akan mengurangi Political Cost sebagai wujud tanggung jawab sosial perusahaan. Perusahaan berukuran lebih besar cenderung memiliki permintaan publik akan informasi yang lebih tinggi dibanding perusahaan yang berukuran lebih kecil (Wahyuningsih \& Mahdar, 2018). 
Pengujian hipotesis keempat menunjukkan bahwa CSR tidak berpengaruh signifikan dan memperlemah variabel Leverage terhadap agresivitas pajak. Agency theory menyatakan bahwa perusahaan yang mempunyai rasio Leverage yang lebih tinggi akan mengungkapkan lebih banyak informasi karena biaya keagenan yang dimiliki perusahaan yang mempunyai struktur modal lebih tinggi. Hal ini juga sejalan dengan stakeholder theory yang mengemukakan bahwa perusahaan tidak hanya beraktivitas untuk kepentingannya sendiri, melainkan juga untuk kepentingan para stakeholder yang terkena dampak atas kegiatan perusahaan seperti supplier, masyarakat, pemerintah, dan pihak-pihak lainnya. Perusahaan yang memiliki agresivitas pajak yang tinggi mengakibatkan perusahaan mengungkapkan CSR yang lebih luas. Hal ini membenarkan legitimacy theory dalam konteks agresivitas pajak yang juga didukung pula oleh teori yang dikemukakan oleh Lanis dan Richardson dalam (Andrianto \& Fadjar, 2017) bahwa perusahaan yang melakukan pengungkapan CSR yang tinggi maka agresivitas pajak yang dilakukan perusahaan tersebut pun tinggi.

\section{$5 \quad$ Simpulan dan Saran}

Firm Size berpengaruh negatif signifikan terhadap tindakan agresivitas pajak, hal ini disebabkan oleh Political Cost yang mana menyebabkan perusahaan besar akan menjadi sorotan pemerintah, sehingga perusahaan besar akan menjaga reputasinya agar tetap baik di mata publik dan pemerintah. Leverage tidak berpengaruh signifikan terhadap agresivitas pajak perusahaan, karena baik perusahaan dengan Leverage yang tinggi ataupun rendah tetap diawasi oleh pemberi pinjaman dan peraturan pemerintah. Corporate Social Responsibility memperlemah pengaruh antara Firm Size terhadap agresivitas pajak, karena pengungkapan yang lebih besar akan mengurangi Political Cost sebagai wujud tanggung jawab sosial perusahaan. Corporate Social Responsibility memperlemah pengaruh antara Leverage terhadap agresivitas pajak karena perusahaan yang mempunyai rasio Leverage yang lebih tinggi akan mengungkapkan lebih banyak informasi karena biaya keagenan yang dimiliki perusahaan yang mempunyai struktur modal lebih tinggi.

Berdasarkan pembahasan dan simpulan yang telah dilakukan, adapun saran-saran yang dapat disampaikan berkaitan dengan judul adalah sebagai berikut:

1. Penelitian selanjutnya disarankan untuk memperpanjang periode pengamatan dan memperluas sektor-sektor perusahaaan yang diteliti sehingga memperoleh sampel yang lebih besar dan hasil penelitian lebih mampu menggambarkan kondisi perusahaan dalam jangka panjang..

2. Penelitian selanjutnya disarankan untuk mencoba menggunakan proksi firm size dan agresivitas pajak yang lain agar firm size dan agresivitas pajak dapat dijelaskan dengan lebih baik, penelitian selanjutnya juga disarankan untuk mempertimbangkan variabel lain untuk dijadikan sebagai variabel moderasi, seperti jenis perusahaan, yang mempunyai kemungkinan berpengaruh terhadap agresivitas pajak.

3. Pihak manajemen perusahaan diharapkan dapat memperhatikan setiap keputusan yang akan dilakukan sesuai dengan peraturan perpajakan yang telah ditetapkan juga lebih memperhatikan aspek pertanggungjawaban sosialnya, tetapi tidak hanya sebatas pemenuhan aturan saja, pihak manajemen perusahaan juga perlu melakukan pemantauan lebih intensif sehingga perilaku agresif terhadap pajak di dalam perusahaan dapat diminimalisir.

4. Bagi pemerintah diharapkan dapat menambah account representative dan auditor pajak untuk meningkatkan pengawasan kegiatan-kegiatan usaha yang kurang menjadi sorotan pemerintah sehingga dapat mengurangi praktik agresif terhadap pajak yang terjadi pada 
perusahaan. Kemudian dalam hal kebijakan mengenai tindakan agresif terhadap pajak agar lebih tegas lagi, karena mengingat belum ada kebijakan dengan sanksi yang nyata terkait agresivitas terhadap pajak.

\section{Daftar Pustaka}

Andrianto, M. R., \& Fadjar , A. (2017). Pengaruh Pengungkapan Corporate Social Responsibility Terhadap Agresivitas Pajak. Profesionalisme Akuntan Menuju Sustainable Business Practice, 862-871.

Anis, I. (2017). Pengaruh Pengungkapan Csr Terhadap Pelaporan Pajak Agresif, Dan Pengaruhnya Terhadap Return Saham. Jurnal Aset (Akuntansi Riset), 9(1), 73-100.

Barli, H. (2018, Juli). Pengaruh Leverage Dan Firm Size Terhadap Penghindaran Pajak (Studi Empiris Pada Perusahaan Sektor Property, Real Estate Dan Building Construction Yang Terdaftar Di Bursa Efek Indonesia Periode Tahun 2013-2017). Jurnal Ilmiah Akuntansi Universitas Pamulang , 6(2).

Dewi, N. P., \& Noviari, N. (2017, Oktober). Pengaruh Ukuran Perusahaan, Leverage, Profitabilitas Dan Corporate Social Responsibility Terhadap Penghindaran Pajak (Tax Avoidance). E-Jurnal Akuntansi Universitas Udayana, 21(1), 830-859.

Fatharani, N. (2012). Pengaruh Karakteristik Kepemilikan, Reformasi Perpajakan Dan Hubungan Politik Terhadap Tindakan Pajak Agresif Pada Perusahaan Yang Terdaftar Dibursa Efek Indonesia Pada Tahun 2007-2010. Universitas Indonesia.

Gunawan, J. (2017, September). Pengaruh Corporate Social Responsibility Dan Corporate Governance Terhadap Agresivitas Pajak. Jurnal Akuntansi, Xxi(03), 425-436.

Katadata. (2019, Februari 11). Gelombang Penghindaran Pajak Dalam Pusaran Batu Bara.

Lanis, R., \& Richardson, G. (2007). Determinants Of The Variability In Corporate Effective Tax Rates And Tax Reform: Evidence From Australia . Journal Of Accounting And Public Policy(26), 689-704.

Lanis, R., \& Richardson, G. (2012). Corporate Social Responsibility And Tax Aggresiveness : An Empirical Analysis. J. Account. Public Policy, 86-108.

Marfu'ah, L. (2015). Pengaruh Return On Asset, Leverage, Ukuran Perusahaan Kompensasirugi Fiskal Dan Koneksi Politik Terhadap Tax Avoidance. Universitas Muhammadiyah Surakarta.

Martinez, A. L. (2017). Tax Aggressiveness: A Literature Survey. Journal Of Education And Research In Accounting, 104-121.

Pranjoto, G. H. (2013). Analisis Leverage (Studi Kasus Pada Perusahaan Yang Terdaftar Di Bursa Efek Indonesia Yang Melakukan Akuisisi). Jurnal Neo-Bis, 7(1).

Sari, N. A. (2018). Pengaruh Profitabilitas Dan Leverage Pada Tax Avoidance Dengan Pengungkapan Csr Sebagai Variabel Pemoderasi.

Sukmawati, F., \& Cyntia, R. (2016, Oktober). Pengaruh Likuiditas Dan Leverage Terhadap Agresivitas Pajak Perusahaan Pada Perusahaan Industri Barang Konsumsi Di Bursa Efek Indonesia Periode 2011-2014. Conference On Management And Behavioral Studies, 498-509.

Wahyuningsih, A., \& Mahdar, M. N. (2018, Februari). Pengaruh Size, Leverage Dan Profitabilitas Terhadap Pengungkapan Csr Pada Perusahaan Manufaktur Yang Terdaftar Di Bursa Efek Indonesia. Kalbisocio, 5(1), 27-36. 